\title{
PENINGKATAN KEPERCAYAAN DIRI REMAJA MELALUI KONSELING KELOMPOK
}

\author{
Tina Aflatin dan SrI Mulyanl Martanlah \\ Universitas Gadjah Mada
}

\begin{abstract}
Pild studies revealed that a great deal of psychological probtems in adolescence stem from lack of self-confidence. The studies also found that peer groups could function both as social support and as a change agent for adolescent. Those findings suggested that group conseling can be used as an alternative intervention to improve self-confidence among adolescents.

The present study tested the efficacy of group counseling in in creasing adolescents' self-confidence. Twenty two sidents of SMA PIRI 1 Yogyakarta who exhibited lack of self-confidence participated in the experimental and control groups. Each group consisted of 11 sudents.

Self-confidence, self-concept, and selfesteem were the dependent measure. Testing were administered 4 times, before treatment, right after treatment, one month after treatment and three months after treatment. Behavioral changes were observed through daily record as well asobserver's rating of subjects behavior during counseling sessions.

$T$-test with gain scores indicated that the increase in confidence differed significantly between experimental and control groups $(t=5.01$; $p<0.05)$. Experimental group $((=28.64)$ showed higher increase in self-confidence than control group $((=1.27)$. The same pattern was shown fr self-concept and self-esteem measures. Behavioral rating scale indicated an increase in self-confidence among subjects of experimental group.
\end{abstract}

Key words: Self-Confidence - Adolescence - Group Counseling.

\section{PENGANTAR}

Tina Afialin adalah dosen Fikultas Psikologi UGM. Menyelesaikan pendidikan sarjana (S-1) dan pascasarjiana (S-2) of Psikologi UGM. Saat in tengah menempuh program S-3 dengan minat utama psikologi Kilinis. Si Mutyani Martaniah adaiah profesor emiritus Fakultas Psikologi UGM dan guru besarFiakultasPsikologi Unika Soegiopranoto Semarang.
T epercayaan diri merupakan aspek 1. kepribadian manusia yang berfungsi penting untuk mengaktualisasikan potensi yang dimilikinya. Tanpa adanya kepercayaan diri maka banyak masalah akan timbul pada manusia. Menurut Koentjaraningrat (1982), salah satu kelemahan generasi muda Indonesia adalah kurangnya kepercayaan diri. Selanjutnya hasil penelitian 
yang dilakukan oleh Afiatin, dkk (1994) terhadap remaja siswa SMTA of Kodya Yogyakarta menunjukkan bahwa permasalahan yang banyakdirasakan dan dialami oleh remaja pada dasarnya disebabkan oleh kurangnya kepercayaan diri. Untuk mengatasi masalah tersebut perlu diupayakan intervensi Untuk meningkatkan kepercayaan diri remaja.

Upaya peningkatan kepercayaan diri bagi remaja yang mengalami hambatan kepercayaan diri dapat dilakukan dengan proses belajar dan berlath (Lauster, 1978; Hambly, 1992). Menu rut Hurlock (1973), remaja yang mengalami masalah kurang percaya diri memerlukan bantuan dengan program peningkatan diri dengan cara konseling. Selanjutnya Egan (1990) menyatakan dengan konseling individu dapat dbantu untuk memperoleh kepercayaan diri karena d dalam konseling individu akan memperoleh umpan balik yang sangat berarti dan berguna Untuk meningkatkan penampilannya. Umpan balik yang paling efektif bagi seseorang dapat diperoleh individu dari interaksinya dalam kelompok (Douglas, 1993). Dengan demikian bentuk konseling yang mungkin lebih tepat bagi remaja adalah konseling kelompok.

Asumsi yang dipakai dalam penelitian ini adalah bahwa dalam konseling kelompok akan terjadi proses interaksi antar remaja. Dalam interaksi tersebut akan diperoleh umpan balik, proses belajar dan berlath perilaku baru, belajar mengekspresikan perasaan, saling memberikan perhatian dan bantuan serta memberikan kesempatan mempelajari ketrampilan sosial. Interaksi tersebut berlangsung dalam suasana yang demokratis sehingga individu akan merasa aman. Selain itu adanya kesempatan Untuk memberikan bantuan kepada orang lain akan menyebabkan individu merasa berarti dan berguna bagi orang lain sehingga menumbuhkan konsep diri yang positif serta harga diri yang tinggi. Selanjutnya hal íni akan meningkatkan kepercayaan diri remaja.

Seorang individu.yang memiliki kepercayaan diri akan memiliki ciri-ciri seperli yang dikemukakan oleh Guilford (1959) dan Lauster (1978) serta instone (1983) sebagai berikut:

1. Individu merasa adekuat terhadap tindakan yang dilakukan. Hat ini didasari oleh adanya keyakinan terhadap kekuatan, kemampuan dan ketrampilan yang dimiliki. la merasa optimis, cukup ambisius, tickak selalu memerlukan bantuan orang lain, sanggup bekerja keras, mampu menghadapi lugas dengan baik dan bekerja secara efektif serta bertanggung jawab atas keputusan dan perbuatannya.

2. Individu merasa diterima oleh kelompoknya. Hal ini didasari oleh adanya keyakinan terhadap kemampuannya dalam berhubungan sosial. la merasa bahwa kelompoknya atau orang lain menyukainya, aktif menghadapi keadaan lingkungan, berani mengemukakan kehendak atau ide-idenya secara bertanggung jawab dan tidak mementingkan diri sendiri.

3. Individu percaya sekali terhadap dirinya serta memiliki ketenangan sikap. Hal ini didasari oleh adanya keyakinan terhadap kekuatan dan kemampuannya. la bersikap tenang, tidak mudah gugup, cukup toleran terhadap berbagai macam situasi.

Sebagai perbandingan akan dikemukakan pula ciri-ciri individu yang kurang percaya diri. Menurut pendapat Lauster(1978); dan Rakhmat (1986) ciri-ciri individu yang kurang percaya diri adalah sebagai berikut:

1. Individu merasa bahwa tindakan yang ditakukan tidak adekuat. la cenderung 
merasa tidak aman dan tidak bebas bertindak, cenderung ragu-ragu dan membuang-buang waktu dalam mengambil keputusan, memiliki perasaan rendah diri dan pengecut, kurang bertanggung jawab dan cenderung menyalahkan pihak lain sebagai penyebab masalahnya, serta merasa pesimis dalam menghadapi rintangan.

2. Individu merasa tidak diterima oleh kelompoknya atau orang lain. la cenderung menghindari situasi komunikasi karena merasa takut disalahkan atau direndahkan, merasa malu jika tampil di hadapan orang banyak.

3. Individu tidak percaya terhadap dirinya dan mudah gugup. la merasa cernas dalam mengemukakan gagasannya dan selalu membandingkan keadaan dirinya dengan orang lain.

Menurut Walgito (1993), untuk membantu individu yang kurang percaya diri dapat dilakukan dengan kebiasaan untuk menanamkan sifat percaya diri. Hal ini dapat dilakukan dengan memberikan suasana atau kondisi demokratis, yaitu individu dilatih berpikir mandiri dan diberi suasana yang aman sehingga individu tidak takut berbuat kesalahan. Dengan adanya suasana demokratis, individu akan dapat melakukan evaluasi diri dan belajar dari pengalaman. Selaniutnya dinyatakan oleh Coleman (1980) bahwa melalui evaluasi diri, remaja dapat memahami diri sendiri dan akan tahu siapa dirinya yang kemudian akan berkembang menjadi kepercayaan diri.

Menurut Natawidjaja (1987), untuk meningkatkan kepercayaan diri remaja-remaja membutuhkan pihak lain yang dipercayalnya untuk mendorong keberaniannya dalam mengambil keputusan. Selanjutnya juga dinyatakan bahwa program konseling kelompok merupakan salah satu upaya untuk memberi bantuan pada remaja dalam si- tuasi yang membutuhkan dorongan. Dengan demikian konseling kelompok merupakan sarana belajar dan berlatih, serta mendapat suasana aman dan demokratis untuk meningkatkan kepercayaan diri remaja.

Konseling kelompok merupakan proses hubungan antar pribadi yang dinamis dan melibatkan fungsi terapi dalam suatu kelompok kecil yang berupaya untuk membantu perkembangan individu (Gazda, 1984; Dixondan Glover, 1984; Natawidjaja, 1984; Fuhrmann, 1990). MenurutOhlsen (dalam Sukiat, 1981), suasana dalam konseling kelompok adalah suasana yang demokratis, yang didasari adanya rasa penerimaan, kepercayaan dan rasa aman serta memberikan kesempatan klien untuk mendapatkan umpan balik dan latihan perilaku bau Selaniutnya dinyatakan bahwa suasana tersebut memungkinkan klien untuk belajar menghadapi, mengekspresikan, dan menguasai perasaan atau pemikiran klien, dengan demikian klien juga mengembangkan keberanian serta rasa percaya diri.

Hasilpenelitian Omizodan Omizo(1984) menunjukkan bahwa pengalaman individu dalam konseling kelompok dapat mengubah konsep dirinya sehingga menjadi lebih positif. Selaniutnya dijelaskan oleh Walgito (1993) bahwa seseorang yang memiliki konsep diri yang positif terhadap dirinya maka orang tersebut akan dapat menghargai dirinya. Hal ini disebut sebagai seseorang yang memiliki harga diri yang tinggi yang selanjutnya menurut Maslow (1970) harga diri yang tinggi merupakan dasar untuk peningkatan kepercayaan diri.

Kepercayaan diri berkembang melalui interaksi individu dengan lingkungannya. Lingkungan psikologis dan sosiologis yang kondusif akan menumbuhkan dan meningkatkan kepercayaan diri seseorang. Lingkungan psikologis dan sosiologis yang kondusif adalah lingkungan dengan suasana 
demokratis, yaitu adanya suasana penuh penerimaan, kepercayaan, rasa aman dan kesempatan untuk mengekspresikan ideide dan perasaan. Lingkungan psikologis dan sosiologis yang tidak kondusif adalah lingkungan dengan suasana penuh tuntutan, tidak menghargai pendapat orang lain dan tidak ada kesempatan untuk mengekspresikan ide dan perasaan.

Kepercayaan diri juga dapat ditumbukkan dan ditingkatkan melalui penanaman sifat-sifat percaya diri dengan belajar perilaku baru, yaitu perilaku percaya diri. Perilaku ini dapat dipelajari dengan mengobservasi perilaku orang lain, selanjutnya berlatih untuk menirunya.

Remaja yang mengalami masalah kurang percaya diri dapat dibantu dengan memberikan lingkungan yang kondusif serta melatihnya untuk belajar perilaku baru yaitu perilaku percaya diri. Lingkungan kondusif yang memberikan kesempatan bag remaja untuk mengekspresikan ide-ide dan perasaannya, menerima dan memberikan dukungan dan bantuan untuk orang lain, serta menerima dan memberikan umpan balik akan menumbuhkan rasa berarti bagi dirinya sehingga ia memiliki konsep diri yang positif. Remaja yang memiliki konsep diri yang positif akan dapat menghargai dirinya, atau dengan kata lain memitiki harga diri yang tinggi. Remaja yang memiliki harga diri yang tinggi akan mampu mengaktualsasikan potensi yang dimiliki atau memiliki kepercayaan diri.

Konseling kelompok merupakan lingkungan kondusif yang memberikan kesempatan bagi anggota untuk saling menerima dan memberi ide, perasaan, dukungan maupun bantuan bagi anggota lain. Dalam konseling kelompok juga ada kesempatan berlatih dan menerima umpan balk untuk mempelajari perilaku baru dan bertanggung jawab atas pilihan yang telah ditentukan sendiri. Suasana ini dapat menumbuhkan perasaan berarti bagi anggota yang selanjutnya dapat menumbuhkan konsep diri yang positi serta harga diri yang tinggi yang akan menumbuhkan dan meningkatkan kepercayaan diri. Dibandingkan dengan konseling individual, konseling kelompok memilki keuntungan karena dalam konseling kelompok anggota dapat memperoleh bantuan dan umpan balik dari konselor dan anggota-anggota lainnya. Selain itu anggota dapat langsung berlatih perilaku baru dalam suatu kelompok dan hasil perilaku tersebut dapat diamati dan dievaluasi baik oleh dirinya sendiri, konselor maupun anggota lain.

Dengan mengikuti konseling kelompok, remaja yang kurang percaya diri akan mendapatkan lingkungan yang kondusif dan alamiah sesuai dengan fase perkembangan serta kesempatan melihat dan berlatih perilaku baru yaitu perilaku percaya diri. Mereka juga akan memperoleh kesempatan untuk saling memberikan dukungan, bantuan dan umpan batik. Hal ini akan menumbuhkan konsep diri yang positif yang selanjutnya akan menumbuhkan harga diri yang tinggi dan meningkatkan kepercayaan diri.

Tujuan penelitian ini adalah untuk mengetahui ada atau tidak peningkatan kepercayaan diri remaja setelah mengikuti konseling kelompok. Tujuan lain yang ingin diketahui pula adalah berapa lama efek konseling kelompok terhadap peningkatan kepercayaan diri remaja.

\section{METODE PENELITIAN}

Penelitian ini dilakukan dengan metode eksperimen, yaitu metode untuk mengetahui pengaruh suatu perlakuan (dalam hal ini adalah konseling kelompok) terhadap variabel tergantung (yaitu kepercayaan diri). Subjek penelitian dibagi menjadi dua kelompok, yaitu kelompok eksperimen 
(mendapatkan konseling kelompok) dan kelompok kontrol (tidak mendapat konseling kelompok), yang diperlakukan sebagal kelompok waiting list, yaitu mendapat konseling kelompok setelah penelitian berakhir

Subjek dalam penelitian ini adalah remaja siswa SMA PIRI I Yogyakarta yang mengalami hambatan kepercayaan diri dengan status kurang sekali, kurang dan atau sedang. Selain itu kriteria yang harus dipenuhi adalah bersedia mengikuti konseling kelompok. Jumlah subjek penelitian 22orang, 11 orangmasukdalarnkelompok eksperimen dan 11 orang lainnya dalam kelompok kontrol. Pembagian subjek ke dalam salah satu kelompok dilakukan dengan random asignment.

Pengukuran kepercayaan diri, konsep diri dan harga diri dilakukan dengan SKPD (Skala Kepercayaan Diri), SKD (Skala Konsep Diri), dan SHD (Skala Harga Diri). Skala kepercayaan diri yang digunakan dalarn penelitian ini didasarkan pada konsep guilford (1959) dan Lauster (1978). Ada tiga aspek kepercayaan diri, yaitu (1) merasa adekuat terhadap apa yang dilakukan, (2) merasa dapai diterima oleh kelompoknya, dan (3) memiliki ketenangan sikap. Pengujian telah dilakukan Pumaminingsih dan Afiatin (1995) yang menunjukkan bahwa skala ini memiliki validitas aitem yang baik dengan koefisien korelasi masing-masing aitem dengan sektor 0,5355 dan koefisien reliabilitas sebesar 0,8644 .

Skala Konsep Diri (SKD) dipakai untuk mendapat data tentang seberapa baik individu mernandang dirinya sendiri yang merupakan hasil pengalaman berinteraksi dengan orang lain. Skala ini disusun oleh Murdoko (1994) yang berisi empat aspek, yaitu aspek fisik, psikis, sosial dan moral. Pengujian yang dilakukan Murdoko (1994) menunjukkan skala ini merniliki indeks daya diskriminasi aitern dengan sekor total bergerak dari 0,351 hingga 0,719 dan koefisien reliabilitasnya sebesar 0,776 .

Skala Harga Diri (SHD) digunakan untuk mengetahui seberapa tinggi tingkat penghargaan subjek terhadap dirinya sendiri. Skala ini disusun oleh Aziez (1994). Pengujian indeks daya diskriminasi aitern yang dilakukan Aziez (1994) menunjukkan bahwa skala ini merniliki indeks dengan diskriminasi aitem yang baik dengan koefisien korelasi masing-masing aitem bergerak dari 0,299 hingga 0,808 dan koefisien reliabilitasnya sebesar 0,825.

Pengukuran dilakukan empat kali, yaitu pada saat pra-perlakuan, segera setelah perlakuan, satu bulan setelah perlakuan, dan tiga bulan setelah perlakuan. Pengukuran juga dilakukan terhadap ketegangan selama mengikuti konseling kelompok ( 7 kali pertemuan).

Untuk mengetahui perubahan perilaku subjek maka selama sesi konseling kelompok dilakukan ratingoleh observerterhadap perilaku subjek. Aspek-aspek yang dinilai meliputi: gerak muka dan kepala, gerak tangan, gerakan dan orientasi tubuh serta komunikasi verbal.

Konseling Kelompok ini terdiri dari tujuh pertemuan. Setiap perternuan berlangsung selama dua jam. Pertemuan dilaksanakan dua kali dalam seminggu, pelaksanaannya berdasar kesepakatan antara konselor dan anggota kelompok.

Konseling kelompok yang digunakan dalam penelitian ini menggunakan pendekatan interaksional-behavioral. Materi pokoknya meliputi: kohesivitas kelompok, pengenalan diri, pemahaman peningkatan kepercayaan diri, umpan balik serta keteladanan dan gladian perilaku percaya diri. Keterangan: 


\section{HASIL ANALISIS DATA KELOMPOK DAN PEMBAHASAN}

Hasil penelitian selengkapnya terdapat pada tabel 1.

Tabel 1. Ringkasan Uji-t Gain Score Skala Kepercayaan Diri, Skala Konsep Diri, Skala Harga Diri antar Kelompok Eksperimen dan Kelompok Kontrol

\begin{tabular}{|c|c|c|c|c|c|c|}
\hline Variabel & Sumber & $\mathrm{n}_{\mathrm{ek}}$ & $\bar{x}_{\mathrm{ax}}$ & $X_{G K}$ & $t$ & p \\
\hline Kepercayaan Diri & $\begin{array}{l}\text { G1 } \\
\text { G2 } \\
G 3\end{array}$ & $\begin{array}{l}11 \\
11 \\
11\end{array}$ & $\begin{array}{l}28,64 \\
29,27 \\
28,64\end{array}$ & $\begin{array}{l}1,27 \\
0,45 \\
2,18\end{array}$ & $\begin{array}{l}5,07 \\
5,53 \\
5,39\end{array}$ & $\begin{array}{l}<0,05 \\
<0,05 \\
<0,05\end{array}$ \\
\hline Konsep Diri & $\begin{array}{l}\mathrm{G} 1 \\
\mathrm{G} 2 \\
\mathrm{G} 3\end{array}$ & $\begin{array}{l}11 \\
11 \\
11\end{array}$ & $\begin{array}{l}34,09 \\
34,72 \\
34,82\end{array}$ & $\begin{array}{l}2,27 \\
2,36 \\
4,00\end{array}$ & $\begin{array}{l}8,56 \\
9,13 \\
9,10\end{array}$ & $\begin{array}{l}<0,05 \\
<0,05 \\
<0,05\end{array}$ \\
\hline Harga Diri & $\begin{array}{l}\mathrm{G} 1 \\
\mathrm{G} 2 \\
\mathrm{G} 3\end{array}$ & $\begin{array}{l}\uparrow 1 \\
+1 \\
+1\end{array}$ & $\begin{array}{l}23,45 \\
23,82 \\
24,18\end{array}$ & $\begin{array}{l}0,27 \\
0,09 \\
0,91\end{array}$ & $\begin{array}{l}12,42 \\
14,60 \\
12,48\end{array}$ & $\begin{array}{l}<0,05 \\
<0,05 \\
<0,05\end{array}$ \\
\hline
\end{tabular}

G1 = selisih sekor pengukuran segera setelah perlakuan dengan pengukuran sebelum perlakuan

G2 = selisith sekor pengukuran 1 bulan setelah perlakuan dengan pengukuran sebelum pertakuan

G3 = selisih sekor pengukuran 3 bulan setelah perlakuan dengan pengukuran sebelum perlakuan

$X_{G E}=$ kenaikan rata-rata kelompok eksperimen

$\mathrm{X}_{\mathrm{GE}}=$ kenaikan rata-rata kelompok kontrol

$\Pi_{\mathrm{E}, \mathrm{k}} \quad=$ jumlah subjek masing-masing kelompok (eksperimen, kontrol).

Tabel 1 menunjukkan bahwa:

1. Ada perbedaan yang sognifikan antara kenaikan rata-rata kepercayaan diri, konsep diri, dạn harga diri sebelum perlakuan dan segera setelah perlakuan antara kelompok eksperimen dan ke- lompok kontrol. Kenaikan rata-rata kelompok eksperimen lebih tinggi daripada kelompok kontrol.

2. Ada perbedaan yang sognifikan antara kenaikan rata-rata kepercayaan diri, konsep diri, dan harga diri sebelum perlakuan dan satu bulan setelah perlakuan antara kelompok eksperimen dan kelompok kontrol. Kenaikan rata-rata kelompok eksperimen lebih tinggi daripada kelompok kontrol.

3. Ada perbedaan yang sognifikan antara kenaikan rata-rata kepercayaan diri, konsep diri, dan harga diri sebelum perlakuan dan tiga bulan setelah perlakuan antara kelompok eksperimen dan kelompok kontrol. Kenaikan rata-rata ke lompok eksperimen lebih tinggi daripada kelompok kontrol.

Hasil rata-rata pemantauan diri terhadap skala ketegangan pada subjek kelompok eksperimen terdapat pada gambar 1 . 


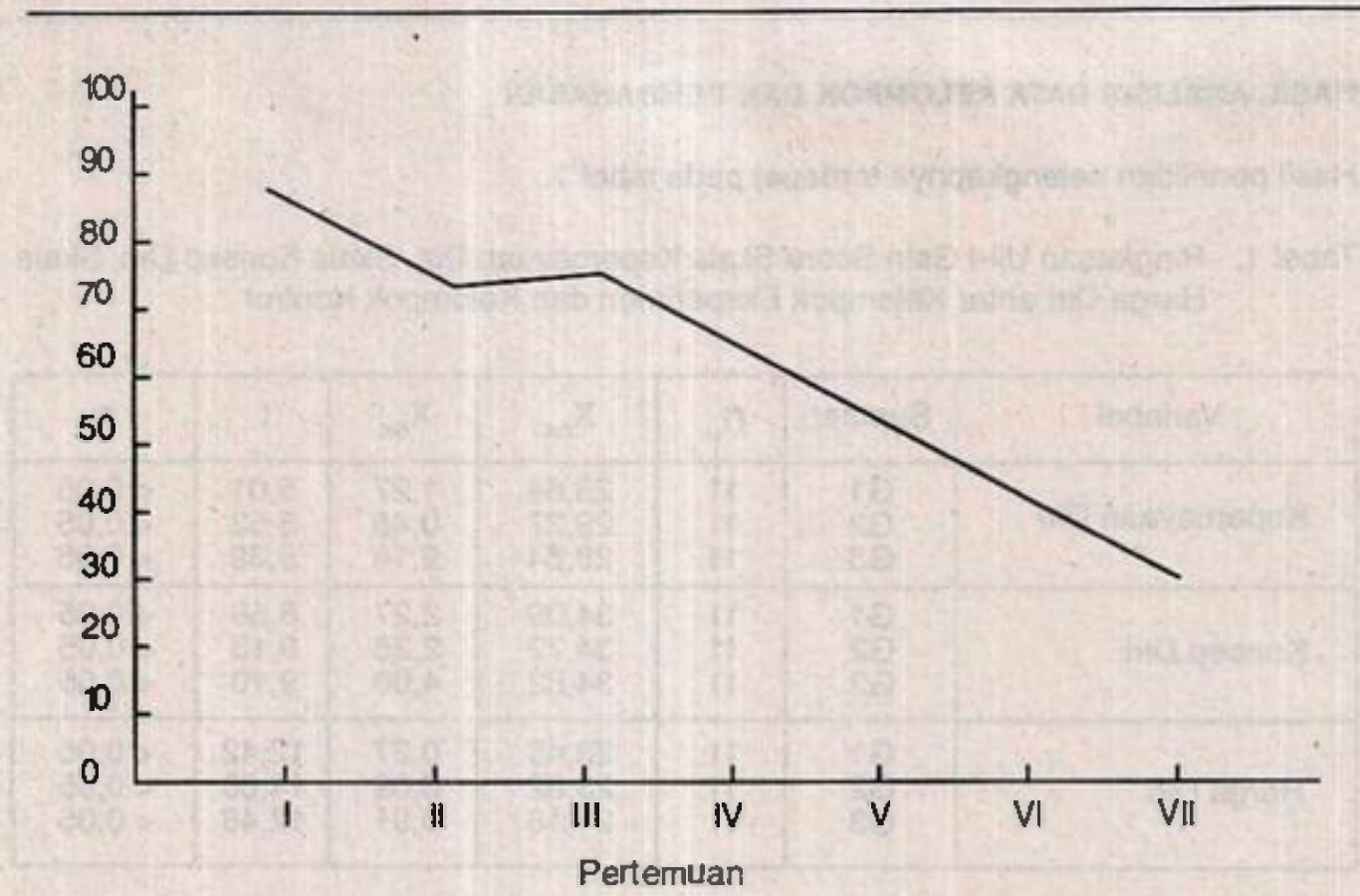

Gambar 1. Hasil Pemantauan Diri Subjek Kelompok Eksperimen Untuk Skala Ketegangan

Gambar 1 menunjukkan bahwa ada penurunan ketegangan selama sibjek mengkuti pertemuan konseling kelompok.

\section{PEMBAHASAN}

Hasil penelitian menunjukkan bahwa ada perbedaan yang signifikan antara peningkatan diri remaja yang mengikuti konseling kelompok dengan remaja yang tidak mengikuti konseling kelompok. Ini mendukung pendapat Ohlsen (dalam Sukiat, 1981); Widjaja (1987); dan Zener (1981). Selain itu juga diperoleh has i bahwa remaja yang mengikuti konseling kelompok juga mengalami peningkatan harga diri serta konsep diri yang lebih positif. Hal ini sejalan dengan penelitian Omizo dan Omizo (1988).

Konseling kelompok dalam penelitian ini menggunakan pendekatan interaksionat-behavior yang menekankan pada kohe- sivitas kelompok, pengenalan diri, pemahaman peningkatan kepercayaan diri. keteladanan dan gladian perilaku percaya diri. Dengan adanya kelompokyang kohesif dalam konseling kelompok, hal ini menimbulkan hubungan antar anggota kelompok yang bersahabat, kooperatif dan demokratis. Menu rut pendapat Johnson dan Johnson (1991) kelompok yang kohesif merupakan sumber rasa aman bagi anggota sehingga dapat mengurangi kecemasan dan meningkatkan harga diri. Peningkatan harga diri pada individu menyebabkan individu dapat menghargai dirinya atau memiliki harga diri positif sehingga akan mempunyai kepercayaan diri yang positif pula (Branden, 1973).

Peningkatan kepercayaan diri melalui konseling kelompok yang menggunakan pendekatan behavioral yaitu dengan ketetadanan dan gladian perilaku ini sejalan 
dengan hasil penelitian Jupp dan Griffitts (1990). Individu yang berhasil dalam gladian perilaku dan bermain peran mengalami perubahan konsep diri menjadi lebih positif. Selenjutnya dijelaskan oleh Maslow (1970) bahwa konsep dini yang positif akan berkembang melandasi harga diri yang tinggi yang akhirnya mengembangkan rasa percaya diri yang ada pada individu. Keberhasilan individu dalam bermain peran khususnya perilaku yang percaya diri akan menumbuhkan perasaan sukses. Menurut Russell (1986) adanya sukses yang dialami akan membuat individu percaya pada dirinya sendiri dan akan membuat atribusi pada kemampuan dirinya terhadap sukses yang telah dicapai.

Hasil penelitian menunjukkan bahwa meskipun secara keseluruhan subjek kelompok eksperimen mengalami peningkatan kepercayaan diri, namun dari hasil analisis individual, peningkatan status kepercayaan diri masing-masing subjek tidak sama. Hal ini disebabkan oleh adanya perbedaan keaktifan masing-masing subjek dalam proses konseling kelompok, termasuk of dalamnya kemauan atau kesediaan untuk berlatih baik d dalam situasi konseling kelompok maupun situasi senyatanya dalam kehidupan sehari-hari. Ternyata subjek yang lebih aktif selama proses di dalam konseling dan ia juga aktif mencoba dalam kehidupan nyata memperoleh kemajuan yang lebih baik daripada subjek yang kurang aktif.

Hásil penelitian ini juga menunjukkan bahwa sangat besar peran kelompok teman sebaya melalui konseling kelompok terhadap perkembangan kepribadian remaja khususnya dalam peningkatan kepercayaan diri. Hal ini sejalan dengan hasil penelitian Afiatin, dkk. (1994) serta pendapat Cohen dan Syme (1985) bahwa kelompok ternan sebaya merupakan sumber dukungan sosial yang berarti bagi remaja. Selanjutnya dijelaskan oleh Hall dan Wellman (dakam Cohen dan Syme, 1985) bahwa dukungan sosial akan efektif bila: pertama, frekuensinya cukup; kedua, pemberi dorongan memegang peranan yang sangat penting dalam proses dorongan sosial; ketiga, peran dorongan sosial akan efektif bila individuindividu yang terlibat memiliki kehangatan hubungan yang tinggi; keempat, bila individu-individu yang terlibat menjalin hubungan timbal balik; dan kellma, bila halhal yang telah disebutkan of atas berlangsung dalam periode waktu yang cukup lama. Proses dalam konseling kelompok memenuhi kelima syarat tersebut sehingga konseling kelompok efektif sebagai sumber dukungan sosial bagi remaja untuk perkernbangan kepribadiannya, khususnya dalam kepercayaan diri. Pada dasamya remaja yang bersekolah menghabiskan sebagian besar waktunya bersama kelompok teman sebaya of lingkungan sekolah, bahkan banyak d antara mereka yang melakukan dan melanjutkan interaksinya di luar sekolah (Hendrojuwono, 1991). Dengan demikian lembaga pendidkan fomal, khususnya SMU (Sekolah Menengah Umum) memiliki potensi besar sebagai wadah kegiatan optimasi interaksi antar remaja. Selanjutnya melalui sekolah, program konseling kelompok remaja ini dapat dilaksanakan dengan melibatkan guru bimbingan dan penyuluhan sebagai konselor kelompok.

Efektivitas konseling kelompok secara intëgratif ditentukan oleh tiga faktor, yaitu: faktor pemimpin kelompok (konselor), anggota kelompok (klien) dan proses atau metodenya (Kemp, 1970; Rose, 1989; Prawitasari, 1991;Afiatin, 1993). Dengandemikian dapat dikemukakan bahwa Modul Konseling Kelompok ini juga akan dapat efektif digunakan apabila memenuhi kriteria meliputi konselor, klien dan proses. Berikut ini akan dijelaskan tentang konselor, klien dan proses yang menunjang efektivitas konse- 
ling kelompok adalah sebagai berikut.

1. Konselor. Konselordan ko-konselor kelompok akan efekttif memandu konseling kelompok apabila mereka telah terlatih dengan baik melalui pengalaman dan supervisi dalam konseling kelompok. Selain itu menurut Johnson dan Johnson (1991) seorang konselor kelompok yang berperan sebagai fasilitator perlu memiliki pengetahuan tentang teori kepribadian, psikopatologi, proses kelompok dan dinamika interpersonal, mereka juga perlu menyadari tentang tingkat sensitivitas pribadi serta sensitivitas untuk menghargai dan menyukai orang lain.

2. Klien. Klien atau anggota kelompok yang diberi intervensi modul ini adalah remaja yang mengalami hambatan kepercayaan diri. Mereka termasuk dalam kriteria sedang, kurang atau kurang sekall. Selain itu subjek akan mendapat kemajuan yang berarti apabila mereka mengikuti konseling kelompok ini dengan sukarela, bukan berdasar paksaan atau tekanan dari orang lain. Subjek memiliki motivasi yang baik, yang ditunjukkannya dengan keaktitannya selama dalam proses konseling kelompok dan juga dalam mencobakan hasil belajamya dalam konseling kelompok ke dalam situasi nyata serta bersedia melakukan evaluasi dan latihan. Jumlah subjek yang mengikułi konseling kelompok berkisar antara 5-12 orang.

3. Proses atau metode. Modul konseling kelompok ini akan elektif apabila dilaksanakan sesuai dengan tahap-tahap atau prosedur yang telah ditetapkan. Modul konseling kelompok ini terdiri dari 10 sesi yang dilaksanakan dalam 7 kali pertemuan. Secara garis besar tahap-tahap dalam modul konseling kelompok ini terdiri dari tahap persiapan, ta hap peran serta, ta hap transisi dan tahap kerja kelompok. Selain itu modalitas penting yang harus ada adalah pembinaan harapan, universalitas, pene- rangan, altruisme, pengulangan korektit keluarga asal, pengembangan teknik sosialisasi (melalui keteladanan, gladian perilaku. dan umpan balik kelompok), rasa kebersamaan, katarsis, eksistensi dan pemahaman diri. Menurut hasil evaluasi subjek, faktorfaktor dalam konseling kelompok yang membantu mereka mengalami kemajuan adalah adanya kohesivitas kelompok sehingga mereka merasa aman, diterima apa adanya dan mampu memahami diri sendiri. Selain itu adanya kesempatan belajar dan berlath sangat membantu mereka dalam peningkatan kepercayaan dirinya.

Apabila ketiga aspek dalam konseling kelompok yang telah disebutkan of atas dapat terpenuhi, maka konseling kelompok merupakan intervensi yang efektit. $\mathrm{Hal}$ ini disebabkan karena konseling kelompok yang efektif dapat memberikan suasana yang kondusif bagi subjek untuk pengembangan dirinya khususnya dalam peningkatan kepercayaan dirinya. Selain îtu subjek juga akan mendapatkan kesempatan untuk berlatih perilaku baru serta mendapatkan umpan balik atas perubahan perilakunya.

Dari uraian d atas dapat dinyatakan bahwa untuk dapat melaksanakan konseling kelompok yang efektit perlu diciptakan suasana kondusif dan dalam hal ini faktor konselor dan ko-konselor banyak berperan. Namun dalam kenyataan ternyata masih relatif sedikit konselor kelompok yang berpengalaman dan terlatih. Hal inilah yang dirasakan sebagai kendala pelaksanaan konseling kelompok baik di sekolah-sekolah maupun dalam kelompok masyarakat. Kendala lain yang dirasa cukup berarti adalah bahwa konseling kelompok memerlukan beberapa kali pertemuan, sehingga diperlukan komitmen subjek untuk menepati kontrak yang telah disepakati. Na mun dalam kenyataan seringkali hal ini berbenturan dengan agenda kegiatan-kegiatan subjek yang lain. Kendala-kendala tersebut 
tentunya perlu diantisipasi dan dicari alternatif solusinya.

Untuk mengantisipasi minirnnya konselor kelompok yang berpengalaman dan terlatih maka perlu diselenggarakan pendidikan dan latihan bagi konselor kelompok, dan tentu saja faktor supervisi yang baik serta kesempatan berlatih menjadi konselor kelompok merupakan faktor yang perlu diperhatikan. Sedangkan untuk mengatasi kendala kedua yaitu komitmen subjek (anggota konseling kelompok) maka perencanaan konseling kelompok perlu memperhatikan waktu pelaksanaan dan agenda kegiatan subjek, misalnya pelaksanaan konseling kelompok dapat dilakukan selama liburan sekolah.

\section{HASIL ANALISIS DATA INDIVIDUAL DAN PEMBAHASAN}

Analisis individual dilakukan terhadap subjek kelompok eksperimen (11 orang).
Data yang dianalisis terdir dari data hasil pengukuran skala kepercayaan diri, skala konsep diri, skala harga diri, lembar ca tatan harian subjek, serta hasil rating observer selama sesi konseling kelompok.

Hasil analisis individual terhadap perubahan sekor serta status kepercayaan diri masing-masing subjek terdapat pada tabel 2

Tabe 2 menunjukkan bahwa perubahan sekor dan status kepercayaan diri masingmasing subjek berbeda. Hal ini dapat ditelusur dari hasil catatan harian subjek serta hasil rating observer selama sesi konseling kelompok menunjukkan bahwa subjek yang lebih aktif terlibat selama proses konseling kelompok mengalami kemajuan yang lebih tinggi daripada subjek yang kurang aktif. Selain itu juga dapat disimpulkan bahwa subjek yang aktif mencobakan hasi belajar dari konseling kelompok ke dalam situasi nyata (kehidupan sehari-hari) serta ada kemauan untuk melakukan evaluasi dan berlath mengalami kemajuan yang lebih berarti daripada subjek yang kurang aktif menco-

Tabel 2 Peningkatan Kepercayaan Diri Masing-masing Subjek Kelompok

\begin{tabular}{|c|c|c|r|c|r|c|c|c|}
\hline $\begin{array}{c}\text { Subjek } \\
\text { No. }\end{array}$ & \multicolumn{2}{|c|}{$\begin{array}{c}\text { Sebelum } \\
\text { Perlakuan }\end{array}$} & \multicolumn{2}{|c|}{$\begin{array}{c}\text { Segera setelah } \\
\text { perlakuan }\end{array}$} & \multicolumn{2}{|c|}{$\begin{array}{c}\text { Satu bulan setelah } \\
\text { perlakuan }\end{array}$} & \multicolumn{2}{|c|}{$\begin{array}{c}\text { Tiga bulan setelah } \\
\text { perlakuan }\end{array}$} \\
\cline { 2 - 8 } & Sektor & Status & Sektor & Status & Sektor & Status & Sektor & Status \\
\hline 1 & 77 & sedang & 92 & cukup & 93 & cukup & 89 & sedang \\
2 & 66 & kurang & 84 & sedang & 84 & cukup & 80 & sedang \\
3 & 60 & kurang & 122 & bak & 120 & baik & 111 & cukup \\
4 & 73 & kurang & 84 & sedang & 88 & sedang & 93 & cukup \\
5 & 85 & sedang & 92 & cukup & 95 & cukup & 99 & cukup \\
6 & 85 & sedang & 113 & baik & 109 & baik & 109 & baik \\
7 & 70 & kurang & 120 & baik & 120 & baik & 122 & baik \\
8 & 75 & sedang & 111 & baik & 112 & baik & 112 & baik \\
9 & 63 & kurang & 108 & cukup & 110 & baik & 110 & baik \\
10 & 84 & sedang & 106 & cukup & 105 & cukup & 106 & cukup \\
11 & 72 & kurang & 92 & cukup & 96 & cukup & 93 & cukup \\
\hline
\end{tabular}


bakan hal tersebut. Subjek yang lebih aktif merasakan bahwa konseling dapat "merupakan sarana untuk berlatih dalam suasana aman dan derrokratis. Meskipun hal tu ka dang-kadang berbeda dengan situasi nyata namun dengan proses berlatih, mencoba, melakukan evaluasi dan berlatih lagi maka timbul keberanian subjek untuk menghadapi situasi nyata dengan cara pandang yang lebih positif.

\section{PENUTUP}

Berdasarkan kesimpulan hasil analisis data kelompok dan data individual serta pembahasan maka dapat dikemukakan kesimpulan hasil penelitian ini sebagai berikut:

1. Konseling kelompok (KK) efektif untuk meningkatkan kepercayaan diri, khususnya bagi remaja yang mengalami hambatan kepercayaan diri. Pengaruh KK terhadap peningkatan kepercayaan diri dapat bertahan sampai 3 bulan setekah konseling kelompok berakhir. Kepercayaan diri setelah mengikuti KK lebih tinggi daripada sebelum mengikuti KK.

2. KK efektif untuk meningkatkan konsep diri khususnya bagi remaja yang mengalami hambatan kepercayaan diri. Pengaruh KK terhadap peningkatan konsep diri dapat bertahan sampai 3 bulan setelah KK berakhir. Konsep diri setelah mengikuti KK lebih baik (tinggi) daripada sebelum menglikuti KK.

3. KK efektif untuk meningkatkan harga diri khususnya bagi remaja yang mengalami hambatan kepercayaan diri. Pengaruh KK terhadap peningkatan harga diri dapat bertahan sampai 3 bulan setelah KK berakhir. Harga diri setelah mengikuti KK lebih tinggi daripada sebelum mengikuti KK.
4. Peningkatan kepercayaan diri subjek selain tampak dalam sekor skala kepercayaan diri, juga tampak dalam perilakunya menurut pengamatan observer.

5. Peningkatan status kepercayaan diri masing-masing subjek tidak sama. Hal ini dipengaruhi oleh adanya perbedaan keaktifan masing-masing subjek dalam proses konseling kelompok. Subjek yang lebih aktif memperoleh kemajuan yang lebih baik daripada subjek yang kurang aktif.

6. Peran kelompok teman sebaya melalui konseling kelompok sangat besar bagi peningkatan kepercayaan diri remaja.

Berdasarkan kesimpulan hasil penelitian yang telah dikemukakan di atas maka dapat diajukan beberapa saran sebagai berikut:

\section{Kepada pemerhatl masalah remaja}

Konseling kelompok tel ah terbukti efektif untuk meningkatkan kepercayaan diri bagi remaja yang mengalami hambatan kepercayaan diri. Oleh karena itu konseling kelompok perlu diberikan kepada remaja khususnya yang mengalami hambatan kepercayaan diri. Penyelenggaraan konseling kelompok dapat dilakukan dalam lembaga pendidikan, sosial dan kemasyarakatan dengan memperhatikan kriteria atau persyaratan pelaksanaan konseling kelompok.

Konseling kelompok sebenarnya merupakan mikrokosmik sosial atau miniatur kehidupan sosial yang nyata. Dengan demikian apa yang telah diperoleh dalam konseling kelompok akan terasa hasilnya untuk perubahan positif individu apabila individu tersebut aktil mencobakan dalam kehidupan nyata. Dalam penelitian ini telah terbukti bahwa subjek yang aktif mencobakan pengalaman yang telah diperoleh dalam konseling kelompok ke dalam ke- 
hidupan nyata temyata memperoleh banyak kemajuan.

\section{Kepada penelit| selanjutnya}

Penelitian ini mengungkap dua variabel utama, yaitu variabel bebas konseling kelompok dan variabel tergantung kepercayaan diri. Pada variabel kepercayaan din, beberapa penelitian lain, misalnya penelitian Instone, dkk. (1983); Syamsiah (1994) dan Thaibsyah (1991) memperhatikan variabel jenis kelamin sebagai prediktor kepercayaan diri, namun hasil yang diperoleh berbeda-beda. Sebagian hasil penelitian menunjukkan ada perbedaan kepercayaan diri antara pria dan wanita, sebagian yang lain menunjukkan tidak ada perbedaan. Dengan demikian perlu kiranya diteliti lebih lanjut apakah ada perbedaan peningkatan kepercayaan diri antara remaja pria dan remaja wanita yang mengikuti konseling kelompok.

Mengingat bahwa konseling kelompok merupakan proses interaksi antar individu yang mengandung fungsi terapi maka kemungkinan konseling kelompok juga efektif untuk memberikan intervensi masalah-masalah remaja yang lain, misalnya: kecenderungan agresivitas, strategi pemecahan masalah yang efektif, dan lain-fain. Kiranya hal inipun perlu diteliti lebih lanjut.

Pada penelitian ini pengukuran kepercayaan diri pad a periode tindak lanjut tidak dilakukan dengan mengamati kinerja subjek, tetapi diberikan skala. Kiranya akan lebih baik apabila pengukuran tindak lanjut selain memberikan skala juga dengan pemantauan diri (self-report) dan pengamatan kinerja subjek oleh observer.

Berdasarkan pengalaman peneliti, karena konseling kelompok ini memerlukan jumlah pertemuan beberapa kali serta waktu yang relatif lama, maka perlu penekanan kontrak persetujuan terhadap subjek. Se- lain itu pelaksanaannya perlu mempertimbangkan agenda kegiatan subjek.

\section{DAFTAR PUSTAKA}

Afiatin, T. 1993. Pertimbangan Konsep dan Metodologi dalam Evaluasi Psikoterapi Kelompok. Makalah. Disusun untuk Memenuhi Jugas Mata Kuliah Penilaian Klinis Program Pascasarjana UGM. Tidak diterbitkan.

Purnamaningsih, E.H.; dan Sofiati, U.M., 1994. Analisis Kebutuhan Tentang Permasalahan Remaja dan Alternatif Pemecahannya. Laporan Penelitian. T.ıkk ditebitkan. Yogyakarta: Fakultas Psikologi UGM.

Aziez, A 1994. Harga Diri Sebagai Prediktor Tingkat Konformitas Remaja terhadap Kelompok Sebaya Sripsi. Yogyakarta: Fakultas Psikologi UGM.

Branden, N. 1973. The Psychology of Self. Esteem. New York: Bantan Book Inc.

Cohen, S. \& Syme, S.L. 1985. Social Support and Health. Tokyo: Academic Press, Inc.

Coleman, J.C. 1980. The Naturg of AdoIescence. London: Methuen.

Dixon, D.N. and Glover, J.A. 1984. Counseling: A Problem Solving Approach. New York John Wiley \& Sons.

Douglas, T. 1993. A Theory of Group Work Practice London: The Macmillan Press, Ltd.

Egan, G 1990. The Skilled Helper. A Systematic Approach to Effective Helping Pacific Grove, Califomia: Brooks/Cole Publishing Company. 
Fuhrmann, B.S. 1990. Adolescence, Ado lescent. Second Edition. Clenview Illinois: A Division of Scott, Foresman and Company.

Gazda, G.M. 1984. Group Counseling: A Developmental Approach. Boston: Allyn \& Bacon, inc.

Guilford, J.P. 1959. Personality. New York: McGraw-Hill Book Company, Inc.

Hambly, K. 1992. Bagaimana Meningkatkan Rasa Percaya Din. (Alih Bahasa: Budiyanta). Jakarta: Arcan.

Hendrojuwono, W. 1991. Meningkatkan Ketahanan Ego dan Kontrol Ego Remaja Melalui "Eksperiential Learning". Ma kalah, disajikan pada Pertemuan Ilmiah Kongres ISPSI ke-5 di Semarang, Desember 199 .

Hurlock, E.B. 1973. Adolescent Development. Tokyo: McGraw-Hill Kogakusha, Ltd.

Instone, D; Major, D, and Bucher, B.D. 1983. Gender, Self Confidence, and Social Influence Strategies: An Organizational Simulation. Journal of Personality and Social Psychology.

Johnson, D.W. and Johnson, FP. 1991. Joining Together: Group Theory and Group Skills. Fourth Edition. Englewood Cliffs: Prentice-Hall, Inc

Jupp, J.J. \& Griffiths, M.D. 1990. Self=Concept Changes in Shy, Socially Isolated Adolescence Following Social Skills Training Emphasising Role Plays. Australian Psychologist, Vol. 25, 165-177.

Kemp, C.G. 1970. Foundations of Group Counseling. New York: McCraw-Hill Book Company.
Lauster, P. 1978. The Personality Test(2nd Ed.). London: Pan Books, Ltd.

Maslow, A.H. 1970. Motwation and Personality. Second Edition. New York: Harper and Row Publisher.

Murdoko, E.W.H 1994. Konsep Diri dan Komunikasi Interpersonal pada Ramaja. Skripsi. Yogyakarta: Fakultas Psikologi UGM.

Natawidjaja, R. 1987. Pendekatan-pendekatan Dalain Penyuluhan Kelompok. Bandung: $\mathrm{CV}$ Diponegoro.

Omizo, M.M. and Omizo, S.A. 1988. Group Conselings Effects on Self Concept and Social Behavior Among Children With Learning Disabilities. Journal of $\mathrm{Hu}$ manistics Education and Development, $26,109-117$.

Prawitasari, JE. 1991. Pendekalan Kelorn pok Dalam Konseling dan Psikoterapi. Malang: IKIP Malang.

Purnamaningsih, E.H. \& Afiatin, T. 1995. Validitas Ekstemal Skala Kepercayaan Diri. Laporan Penelitian. Yogyakarta: Fakultas psikologi UGM.

Raharjo, M.D.I. 1991. Hubungan Antara Penyingkapan Diri Dengan Kesepian pada Remaja Di Yogyakarta. Skripsi. Tidak Diterbitkan. Yogyakarta: Fakultas Psikologi UGM.

Rakhmat, J. 1986. Psikologi Komunikasi. Bandung: Remaja Karya.

Rose, S.D. 1989. Working With Adults in Group: Integreting Cogniffve-Behavioral and Small Group Strategies. San Francisco: Josey-Boss Publishers.

Russell, D. 1986. Causal Altributions, Causal Dimensions, and Affective Reactions to 
Success and Failure. Joumat of Personality and Social Psychology, 50, 1174. 1185.

Sukiat, 1981. Konseling Kelompok. Kumpulan Naskah Penataran Bimbingan dan Konseling untuk Tenaga. Pengajar Perguruan Tinggi se-indonesia. Departeman Pendidikan dan Kebudayaan.

Syamsiah, S. 1994. Pengaruh Keikutsertaan Dalam Program Pengembangan Pribadi Terhadap Rasa Percaya Diri Pada Siswa Sekolah Pengembangan Pribadi John Robert Powers Jakarta. Skripsi. Tidak Diterbitkan. Yogyakarta: Fakultas Psikologi UGM.
Thaibsyah, M.l. 1991. Pengaruh Sistem Lathan Bela Diri Katedo Indonesia Terhadap Rasa Percaya Diri Pada Siswa Bela Diri Katedo indonesia. Skripsi. Tidak Diterbitkan. Yogyakarta: Fakultas Psikologi UGM.

Waigito, B. 1993. Peran Orang Tua dalam Pembentukan Kepercayaan Diri Suatu Pendekatan Psikologi Humanistik. Pidato Pengukuhan Jabatan Guru Besar Dalam limu Psikologi pada Fakultas Psikologi Universitas Gadjah Mada. Yogyakarta, 4 September 1993. Tidak Diterbitkan. 